\title{
Inledning till studier av professioner och professionellt arbete
}

\section{LENNART G SVENSSON}

Detta temanummer handlar om studier av professioner och professionellt arbete. Det består av fem artiklar som avser att dels ge en insyn i och en överblick av studiefältet, dels ge inspiration till fortsatt egen läsning på fältet och kanske också för egen forskning. Förhoppningsvis kan artiklarna också användas $i$ undervisning.

I skrivande stund med omfattande kritik mot vinstdrivande privata företag inom äldreomsorgen, där man nu efterfrågar skarpare kvalitetskontroll av vad som levereras, ligger det nära tillhands att peka på denna enkla betydelse av profession: ett yrke med en längre utbildning som avser att säkra kompetens för vissa arbetsuppgifter utan annan kontroll än kollegornas och klienternas. Diskussioner om att definiera profession och professionell har varit legio i professionsstudier genom tiderna. I detta nummer ska mindre möda ägnas detta. Men det kan ändå vara på sin plats att här inledningsvis säga något kort om detta. Och den kortaste definitionen är kanske att vara omdömesgill, vilket omfattar såväl kompetens som ansvar. Definitioner av professioner tar ofta fasta antingen på en organisatorisk aspekt som kollegiali- tet under autonomi, eller en kunskapsmässig (epistemisk) aspekt som vetenskapligt (abstrakt) kunskapsbaserat utförande av vissa arbetsuppgifter. I vissa definitioner förekommer båda aspekterna (Molander \& Terum 2008). Profession och professionalism används också ofta som ett värde i sig eller som en ideologisk övertygelse för att legitimera beslut, diagnoser, tolkningar och åtgärder. I den betydelsen har begreppen brett ut sig avsevärt - inte minst inom stora och mer eller mindre professionella organisationer. Professionalisering och professionalism är också starkt efterfrågade som strategier för yrken och organisationer och som önskvärd kompetens hos enskilda yrkesutövare. Begreppen är mycket positivt laddade. Den vanligaste användningen eller betydelsen av professionalism är helt enkelt yrkeskunnig (Svensson 2011:35).

Just $i$ år införs lärarnas statliga legitimation som länge varit hett eftertraktad av Lärarnas riksförbund. Därmed betonas den formella utbildningen som grund för yrkesutövningen, vilket inte varit så vanligt på senare tid, då kraven på utvärderingar och uppföljningar istället framhållits. Förändringar inom skolan och för lärarna sam- 
manfattas i en aktuell artikel på följande sätt som har stor allmängiltighet vad gäller politiska mål för medborgerliga rättigheter. "Den professionelle ska visserligen vara välutbildad och certifierad - något som är nödvändigt för strategins legitimitet - men det är [nu] inte de professionellas värderingar som ska styra verksamheten. Det ska ske genom management (överförande av makt till skolledningen), valfrihet för kunder, konkurrensutsättning och standardisering, uppföljning och utvärdering. Samtliga dessa processer flyttar fokus från skolans kärnverksamhet (undervisning) till olika legitimitetsskapande processer för skolledning, kommunledning och stat." (Stenlås 2011:35) Denna nyliberala agenda som också omfattar skattesänkning, avreglering, privatisering, marknadisering och starkare ledarskap i organisationer, har haft något starkare stöd bland vissa professionella grupper än hos andra. Den har legitimerats av valfrihet, skattereduktion, entreprenörskap och privat företagsamhet. Den har främst riktats mot offentlig tjänsteproduktion av utbildning, vård och omsorg med i huvudsak kvinnor som anställda - därmed också kvinnligt dominerade yrkesgrupper. Skillnader vad gäller resurser mellan olika yrken och sektorer i vad man kan kalla det professionella skiktet har ökat.

\section{Det professionella skiktet}

Det professionella skiktet i ett samhälle formas huvudsakligen av forskning, utbildning, yrkes- och arbetsliv samt allmänhetens eller medborgarnas efterfrågan på tjänster. Politiska organ och statliga myndigheter sätter en del av de ekonomiska och organisatoriska villkoren för dessa samhällsinstitutioner. Nordisk tradition för hur arbetslivet organiseras bjuder emellertid stort inflytande för förhandlingar mellan parter på arbetsmarknaden. Företagare och anställda där är dessutom i mycket hög grad anslutna till sådana organisationer. Det gäller i synnerhet yrken med längre utbildning, där man har en anslutningsgrad av anställda kring 90 procent. Sveriges akademikers centralorganisation (SACO) är den samlande organisationen för fackligt organiserade akademiker och består av 23 självständiga fackförbund. Federationen SACO har drygt 600.000 medlemmar (inklusive studenter). SACO:s förbund företräder yrkes- och examensgrupper från hela arbetsmarknaden, inklusive vissa egenföretagare. Det som förenar medlemsförbunden är akademiska högskoleutbildningar. Dessa har sedan 1970talet efterhand utvidgats att omfatta en rad utbildningar som gjort anspråk på och också bildat nya professioner med starkare organisationer som lärare, socionomer och sjuksköterskor. En del av dessa finns kvar inom Tjänstemännens centralorganisation (TCO). Vissa förbund består av ett dominerande yrke med en gemensam examenstitel, som Sveriges läkarförbund med läkare baserade på läkarexamen och med några yrkesföreningar enligt hälso- och sjukvårdens organisering och en lång rad specialistföreningar enligt specialistutbildningar och yrkesverksamheter. Andra förbund består av flera yrken som Akademikerna SSR, där socionomutbildningen har blivit den dominerande. SACO organiserade från 
början 1947 vad man kan kalla kärnprofessionernas yrkesutövare och högre tjänstemän. Tjänstemännens centralorganisation TCO har organiserat semiprofessioner och lägre tjänstemän samt tjänstemän på mellannivå. Reformer av högre utbildning, så att all eftergymnasial utbildning kommit att ingå i högskolan, har närmat de båda organisationernas rekryteringsgrunder till varandra.

I den svenska befolkningen i yrkesverksam ålder (25-64 år) har 23 procent minst treårig högskoleutbildning. Av de fackligt organiserade är 18 procent medlemmar i SACO, och de utgör en stor del av dem som kan räknas som professionella i arbetskraften. De utgör vidare ett urval av befolkningen så att de i större utsträckning kommer från akademikerhem och medelklasshem och oftare bor i större tätorter. Drygt hälften av SACO-medlemmarna är numera kvinnor - en ökning från 36 procent 1982 till över 46 procent 1997. Men de är mycket olika fördelade på förbund och därmed yrken. Den svenska arbetsmarknaden är starkt könsuppdelad med i stora drag offentliganställda kvinnor i vård, omsorg och utbildning och privatanställda män inom tekniska yrken, byggnad och transport, vilket medverkar till olika arbetsvillkor. Journalister, tandläkare och veterinärer är tre exempel på professionella yrken som har klar majoritet av kvinnor i den yngsta åldersgruppen och som därmed kommer att ytterligare feminiseras. Män är däremot i fortsatt majoritet bland civilingenjörer, poliser och systemvetare (SCB 2010:10).

Det svenska professionella skiktet är alltså knappast särskilt avgränsat och sammanhållet. Istället består det av en rad olika utbildningar och yrken med olika villkor och värderingar. Många yrken är vidare starkt differentierade inbördes $i$ olika specialiteter. En del yrken är också skilda på olika typer av anställningar med mycket olika villkor som t.ex. socionomer som socialsekreterare eller som privatpraktiserande terapeuter. Ifråga om vissa politiska åsikter och värderingar skiljer det professionella skiktet ut sig något från allmänheten. I en enkätstudie 1996 visade sig SACO-medlemmar vara mera positiva till förslaget att minska den offentliga sektorn, att överföra statlig affärsverksamhet i privat regi, att låta privata företag svara för äldreomsorg, att öka antalet friskolor och att bedriva mera av sjukvård i privat regi (Svensson 2002). Men skillnaderna mellan olika yrkesgrupper var dock mycket stora. Socionomer, psykologer och präster var t.ex. starkt emot förslaget att minska den offentliga sektorn, medan advokater, ekonomer och ingenjörer var starkt för. De yrkesgrupper som var signifikant splittrade inom sig angående åsikten om att minska den offentliga sektorn var: civilekonomer, samhällsvetare, psykologer, läkare, tandläkare och veterinärer. Om man kontrasterar de fyra grupperna åsiktsmässigt på vänsterkanten (socionomer, psykologer, präster och universitetslärare) med de fyra på högerkanten (advokater, ekonomer, tandläkare och civilingenjörer) finner vi avsevärt större andel kvinnor och offentliganställda bland de förra och män och privatanställda bland de senare. Man kan därmed konstatera att SACO-medlemmarna på 1990-talet utgjorde ett aggregat eller ett skikt av professionella som var mer nyliberalt än allmänheten men samtidigt 
starkt fragmenterat på såväl kön och sektor som yrkesgrupp. Drygt hälften av grupperna var 1996 positiva till att minska den offentliga sektorn. År 2010 däremot återfanns på den positiva sidan i den frågan bara ekonomer och ingenjörer. ${ }^{1}$ Inställningen till att minska offentlig sektor och att öka antalet friskolor har sedan 1996 kraftigt förändrats bland professionella. Spännvidden inom skiktet som helhet är inte längre alls lika stor. Men psykologer och socionomer utmärkte sig även $2010 \mathrm{att}$ hysa starkast motstånd mot att minska den offentliga sektorn. Tilläggas kan att andelen motståndare bland allmänheten varit något större än anhängarna i samma fråga ända sedan början på 1990-talet (Holmberg m. fl. 2011:45).

Det professionella skiktet har dock i allmänhet bättre arbetsvillkor och löner än flertalet andra anställda. Men också därvidlag är variationerna mycket stora mellan olika yrken och anställningar. En sak delar man dock, och det är att vara självständig i sin yrkesutövning i det direkta arbetet. Eget yrkeskunnande och den egna yrkespersonen, menar man, är vad som bestämmer arbetet. Detta är ett mycket tydligt resultat bland respondenterna både i 1996 och 2010 års enkätstudier. Det kan samtidigt sägas höra till det främsta professionella anspråket. Det är kanske bara i den meningen som det finns någon slags potentiellt professionellt kollektiv som baseras på kollegiala former av autonomi.

1 Pågående enkätstudie vid Lunds universitet under ledning av Thomas Brante, finansierad av Forskningsrådet för arbetsliv och socialvetenskap.
Professionella yrken har också i allmänhet högre status bland allmänheten än andra yrken. Uppfattningar om yrkens status är mycket stabila över tid. Variationerna mellan yrkena är emellertid stora t.ex. enligt ett urval om hundra yrken hamnade följande på plats nummer: läkare (2), domare (3), professor (4), advokat (5) civilingenjör (9), gymnasielärare (44), sjuksköterska (48), skolkurator (51), grundskollärare (52), socialsekreterare (61), bibliotekarie (64) och förskollärare (65) (Svensson \& Ulfsdotter Eriksson 2009). Professionella är mycket beroende av förtroende från omgivningens politiker, chefer, klienter och allmänhet. Här spelar numera medias bilder av yrken en avgörande roll och visar om man rätt kan kontrollera yrkesutövarna eller ej. Förtroendet hos allmänheten varierar också stort mellan olika yrken: från tandläkare, läkare och sjuksköterskor i toppen till officerare och journalister i botten (Svensson 2011). Professionellas egen bedömning av allmänhetens skattning stämmer mycket väl överens med allmänhetens skattning, vilket gör att professionella också uppfattar stora skillnader mellan olika yrkesgrupper. Rangordningarna av yrkena enligt professionellas och allmänhetens skattningar är så gott som identiska. SACO-medlemmarna eller de professionella visar sig på det sättet vara en del av befolkningen snarare än något avvikande skikt.

I ett längre historiskt och i ett internationellt jämförande perspektiv utmärker sig professionella yrken och yrkesorganisationer genom att anpassa sig väl till nya villkor. Konflikter, strider och motstånd är knappast kännetecknande för det professionella skiktet, även om strejker har före- 
kommit vid enstaka tillfällen i Norden bland SACO- och TCO-grupper under de senaste femtio, sextio åren. De nyliberala förändringarna och deras konsekvenser har förvisso under de senaste 20 åren i Sverige mötts av kritisk debatt i många förbund och förbundstidskrifter. Enstaka gemensamma aktioner som t.ex. några läkares och sjuksköterskors uppsägning vid ett eller annat sjukhus, har också förekommit. Men kollektiva aktioner av större omfattning lyser ändå med sin frånvaro. Professionella grupper och yrkesutövare antar snarare anpassning till nya villkor och söker med förhandlingar och organisatoriska strategier att värna sina positioner och privilegier. En organisatorisk strategi är att utvidga domänen eller marknaden för sin kompetens och abstrakta kunskap. En annan är att yrket delas upp i nya strata som i lärarnas fall i samband med kommunaliseringen och ny skolorganisation, att skolledarnas antal då ökade kraftigt och skildes ut tydligare från lärarna. På det hela taget har denna anpassning handlat om att professionella blivit delaktiga i arbetsorganisationerna och ansvariga för deras mål och resultat på ett nytt sätt. Vi kan tala om en ny organisationsprofessionalism till skillnad från en äldre yrkesprofessionalism (Evetts 2010; även Liljegren \& Parding 2010). Vad gäller kunskap baseras den förra på kompetenskrav i arbetet till skillnad från en formell abstrakt kunskapsmassa (Muzio \& Kirkpatrick 2011:457). Vad gäller legitimitet finner organisationsprofessionalismen den i marknadsvärde till skillnad från det allmänna bästa. Vad gäller relation till staten att inte vara beroende av statlig legitimation och reglering i samma utsträckning som yrkesprofessionalismen. Organisationsprofessionalismen utmärks slutligen av att ha nära relationer till klienter och arbetsgivare till skillnad från yrkesprofessionalismens distans i dessa avseenden.

\section{Professionsstudier}

Som framgår av den första artikeln (Riska) i detta temanummer har studier av och teorier om professioner en lång tradition $\mathrm{i}$ sociologin från ämnets klassiker som Max Weber, Emile Durkheim och Talcott Parsons via en rad andra sociologer som tog fasta på vissa egenskaper hos yrken som ansågs skilja ut dem som professioner och senare åter andra som kritiskt granskade yrkesmonopol i sin samhälleliga kontext - ibland utifrån klassperspektiv. Thomas Brante benämnde dessa två senare traditioner den naiva respektive den cyniska (Brante 1987). Den naiva var knuten till en funktionalistisk samhällssyn, medan den relationella, nyweberianska, var knuten till en konfliktorienterad samhällssyn. Egenskaperna som t.ex. längre akademisk utbildning, licensiering, yrkesspråk, förbund och etikkod har emellertid återkommit och fogats in i senare studiers relationella ansatser som exemplifieras med Andrew Abbott och Pierre Bourdieu i den andra artikeln (Carlhed), där deras konfliktorientering poängteras. Samtida ansatser som söker utveckla och ta fasta på vissa egenskaper är David Sciulli (2010) och Thomas Brante (2011).

Professionsstudier kan ha ansatser som härrör från en rad andra discipliner. Från filosofi hämtar man t.ex. definitionstyper 
och metoder för begreppsutveckling som exemplifieras i detta nummer av den fjärde artikeln (Molander) om skön och diskretionärt arbete. Ämnet historia bidrar med studier av yrkens historia och utveckling liksom hela det professionella komplexets relationer till stat, utbildning, familj och andra samhällsinstitutioner. Detsamma kan sägas gälla statsvetenskap jämte studier av makt, legitimitet, styrning och förtroende. Från kunskapssociologi hämtas t.ex. studier av kognitiva och epistemiska frågor och kunskapstypologier. Relationer till utbildningssociologi rör studier av utbildningsinstitutioners utveckling och förändring och betydelse för yrkens och professioners utbildning och rekrytering. Här handlar det också om relationer mellan formell utbildning och professionell praktik och hur man med t.ex. praktikinslag överbryggar vad som ofta framhålls som vida klyftor mellan två olika världar. Organisationssociologi kan bidra med studier av det professionella arbetets olika organisatoriska kontexter och villkor. Den tredje artikeln är ett exempel på detta (Svensson). Arbetssociologi och yrkessociologi slutligen kan bidra med mycket om arbetens och yrkens miljöer, villkor och värderingar.

Professionsstudier har tidigare haft sin huvudsakliga plats och utveckling inom sociologin. Men de återfinns sedan länge också i en rad andra discipliner som pedagogik, ekonomi, juridik, statsvetenskap, socialt arbete och hälsovetenskaper. En sökning på avhandlingar i professionsstudier (både nationella och internationella) på Libris gav drygt 500 träffar under senaste decenniet och cirka 300 föregående decennium och något färre ytterligare ett decen- nium bakåt i tiden. Flertalet avhandlingar rör enbart ett professionellt yrke och skrivs ofta inom detta yrkes forskarutbildning som en slags inifrånstudie och handlar ofta om relationen mellan utbildning och yrke (Kullberg 2011). I en del fall är det pedagoger eller sociologer som skriver om andra yrken (Björkdahl Ordell 1990; Einarsdottir 1997; Wingfors 2004; Persson 2009). Mer sällan rör det sig om jämförande studier mellan yrken och mellan länder eller om allmänna fenomen hos professioner. Den sortens litteratur anges däremot i den första artikeln (Riska). I norden finns ett enda centrum för professionsforskning som ger särskild forskarutbildning i professionsstudier, nämligen Senter for profesjonsstudier vid Högskolan i Oslo. Forum för professionsforskning vid Linnéuniversitet och Centrum för professionsstudier vid Malmö högskola är exempel på två enheter i Sverige som ger viss forskarutbildning. Många andra högskoleinstitutioner ger särskilda kurser i professionsstudier. Inslag av professionsstudier ges också i många fortbildningar som arrangeras av yrkesförbund. Många lärosäten, särskilt högskolor, har ambitionen att skapa en slags professionsprofil. Det gäller t.ex. Högskolorna i Oslo och i Malmö, där deras respektive centra ska bidra med forskning och utbildning $i$ professionsstudier som service åt hela högskolan och därmed medverka till att stärka de olika professionsinriktade utbildningarna. Och högskoleutbildningar för yrken med professionella anspråk fortsätter att öka liksom utbildningar med anspråk på att utbilda med sikte mot professionella yrken (Olofsson \& Petersson 2011). Denna antologi visar en viktig trend i högskolans 
yrkesorienterade program. Allt fler utbildningsprogram som redan finns i högskolans regi utvecklar tydliga professionsanspråk. Samtidigt växer antalet yrkesorienterade utbildningar som vill nå högskolestatus. Men både bland chefer och anställda i vissa verksamheter råder ändå ibland ambivalens till att med längre högskoleutbildning nå högre kompetens i arbetet med klienter. Ett exempel på detta är det femte bidraget i detta nummer om funktionshinderverksamhet och äldreomsorg (Dunér \& Olin).

Många professionsstudier har sett yrken och professionella yrkesorganisationer som aktiva agenter för att driva sina egna projekt - särskilt i den kritiska, cyniska eran (Sarfatti-Larson 1977; Freidson 1970, 1986; Abbott 1988). Andra ekonomiska och organisatoriska villkor i och med de nyliberala förändringarna har gett en annan bakgrund till en rad studier sedan tidigt 1990-tal, där professioner ofta ses som offer för omständigheter som de antas försvara sig mot (Freidson 2001). Då rör det sig mest om professioner i offentlig sektor och s.k. välfärdsprofessioner, vars etablering skedde mer på statliga organisationers initiativ uppifrån och som också varit starkare statligt reglerade. Sådana studier inleds ofta med att sammanfatta det nya ledarskapet (New public management) och dess konsekvenser på området. (Exempel på detta ges i temanummer: i Current Sociology Juli 2006 volym 54:4; i Journal of Sociology, The Australian Sociological Association, volym 45:4; i nummer 3-4 av Socialvetenskaplig tidskrift 2010 liksom i nummer 4 av Arbetsmarknad \& Arbetsliv 2011.)

En annan typ av professionsstudier finner vi hos forskare på handelshögskolor och motsvarande, där man tagit över en del av de sociologiska ansatserna. Det handlar t.ex. om chefer, affärsjurister, revisorer, konsulter och andra experter i numera ofta stora globala professionella byråkratier i det privata näringslivet. (Flera exempel på sådana studier återfinns i temanummer av Current Sociology 2011, volym 59:4). Ett första omfattande tema i dessa studier är professionellas anpassning till och uppgående i dessa arbetsorganisationer, där professionella i olika konstellationer driver sina intressen med hjälp av organisationernas resurser (allt oftare i egna utbildningar) och med dem skapar gränser och uteslutningar snarare än med hjälp av offentlig formell utbildning och licensiering (Brint 1994; Ackroyd 1996; Scott 2008; Faulconbridge \& Muzio 2008; Noordegraaf 2011) Ett andra omfattande tema är att ledningar i dessa organisationer tagit upp professionalism som värde och ideologi, som man i internutbildningar, kampanjer och varumärken använder för att på distans styra anställda professionella som ofta arbetar utom räckhåll för chefernas direkta insyn - en professionalism som fokuserar på individer och deras lojalitet (Fournier 1999; Alvesson 2001, 2002; Evetts 2010). Ledarskap, konkurrens och kommersialism ersätter partnerskap, kollegialitet och förtroende (Brint 1994; Hanlon 1998), vilket gör dessa professionella byråkratier immuna mot de respektive yrkesorganisationernas normativa påtryckningar (Muzio \& Kirkpatrick 2011:394).

Trots att professionssociologi länge varit ett eget forskningsfält med mycket god representation vid nationella och interna- 
tionella konferenser - särskilt från hälsoprofessioner - så har det märkligt nog inte funnits någon särskild tidskrift $\mathrm{i}$ denna sociologi eller i det mer allmänna "professionsstudier" förrän i skrivande stund. Första numret av den fritt tillgängliga nordiska och internationella nättidskriften "Professions and Professionalism" har just publicerats. Tidigare har publicering av professionsstudier främst skett $\mathrm{i}$ ämnesspecialiserade tidskrifter - särskilt på hälsofältet. Men artiklar har också förekommit i t.ex. "Work and Occupation", "Work and Employment", "Organization", "Organization Studies", "Current Sociology" och "European Societies".

Ett svenskt mångdisciplinärt "Nätverk för professionsstudier" med medel från Forskningsrådet för arbetsliv och socialvetenskap och närmast knutet till Centrum för professionsstudier vid Malmö högskola och Forum för professionsforskning vid Linnéuniversitetet har funnits i några år. Det kommer under år 2012 att uppgå i ett mångdisciplinärt "Nordiskt nätverk för professionsforskning" (Nordpro) som är knutet till den nya tidskriften "Professions and Professionalism". Ännu saknas en engelsk handbok i professionsstudier av det slag som mer etablerade sociologiska forskningsfält har. Det finns dock en bok på norska som har karaktär av handbok "Profesjonsstudier" (Molander \& Terum red. 2008). Här är några andra exempel på nordiska antologier i professionsstudier under senare år.

- Gytz Olesen, Sören (red. 2012) Professionernes sociologi og vidensgrundlag. Kbh: Systime.

- Bohlin, Ingemar \& Sager, Morten (red.
2011) Evidensens många ansikten: Evidensbaserad praktik ipraktiken. Lund: Arkiv.

- Svensson, Lennart G \& Evetts, Julia (red. 2010) Sociology of Profession: Continental and Anglo-Saxon Traditions. Göteborg:Daidalos.

- Fransson, Ola \& Jonnergård, Karin (red. 2009) Kunskapsbehov och nya kompetenser: Professioner i förhandling. Sthlm: Santérus Academic Press.

- Jonnergård, Karin \& Funck, Elin, K \& Wolmesjö, Maria (red. 2008) När den professionella autonomin blir ett problem. Växjö University Press.

- Aili, Carola; Nilsson, Lars-Erik; Svensson, Lennart G \& Denicolo, Pamela (red. 2007) In Tension between Organization and Profession: Professionals in Nordic Public Service. Lund: Nordic Academic Press.

Se även skriftserien "Vetenskap för profession" vid Högskolan i Borås.

\section{Bidragen i detta temanummer}

Elianne Riska sammanfattar i sin artikel de främsta teoretiska frågorna i den professionssociologiska diskussionen och traditionen. Här presenteras de centrala professionsstudierna som ofta återkommer i detta sammanhang. Hon använder läkarprofessionen som modellexempel, men teorierna och studierna har tillämpning också inom andra yrken och fält. Den första delen av artikeln redogör för de funktionalistiska, interaktionistiska och nyweberianska perspektiven samt systemteorin och det post-strukturalistiska perspektivet på läkarprofessionens särställning i jämförelse med andra hälsoprofessioner. I senare 
studier har de äldre ledande teoretiska perspektiven kritiserats för att de har varit könsneutrala och för att de har bortsett från vad kvinnor tillför hälsovården. Den andra delen av artikeln presenterar därför ett genusperspektiv på frågan om orsaker till yrkesgruppers över- och underordning $i$ hälsovården.

Riska visar för det första att professionssociologin präglats av en förvånansvärt stor konsensus under olika epoker i jämförelse med andra sociologiska delområden. Det nyweberianska konfliktperspektivet har dominerat professionsstudier under en stor del av den femtio år långa observerade perioden. Studier av hälsoprofessioner är idag mer eklektiska än tidigare. För det andra visar hon att läkarprofessionen har utgjort en proto- eller idealtyp av en profession i teoribildningen om professioner. Det gäller främst läkarprofessionens specifika kunskapsbaserade och etikrelaterade egenskaper vis a vis andra yrkesgrupper. Därmed har man delvis försummat professionaliseringen av andra hälsoyrken. För det tredje presenterar Riska genusperspektivet i professionsforskningen och hur det lyft fram kvinnors underordnade roll i hälsovården. I den avslutande delen pekar hon på de teoretiska utmaningar som nationellt avgränsade studier om hälsoprofessioner står inför i samband med internationalisering och globalisering.

Carina Carlhed utgår i sitt bidrag från en av de länge ledande teoretikerna som Riska presenterar, nämligen Andrew Abbott och hans system- och konfliktperspektiv. Hon undersöker likheter och skillnader i det perspektivet med Pierre Bourdieus fältteori och vad den kan tillföra stu- dier av professionella praktiker. Hon jämför Pierre Bourdieus ansats med Andrew Abbotts dominerande professionsteoretiska perspektiv. Hennes diskussion rör teman som systemiskt och relationellt tänkande, teori som öppna ramverk eller program, deras konfliktfokus och olika nivåer för konflikterna, mytbildning, kunskap som legitimerande funktion och slutligen autonomifrågan. Hon visar hur både Abbott och Bourdieu arbetar empiriskt och att båda förespråkar löst hållna definitioner av professioner. Båda teoretikerna har vidare ett konfliktperspektiv och en relationell ansats. De uppfattar målen för striderna att vinna kulturell legitimitet, där en primär metod är att skapa image eller myter. Exempel på skillnader är deras syn på gränser och kärnområden, där Abbott fokuserar gränserna, och Bourdieu det som håller samman fältet. Bourdieu lägger mer fokus på kulturella och symboliska maktstrukturer och deras sociala reproduktion. Abbott har ett starkare konfliktperspektiv, medan Bourdieu pekar på andra drivkrafter som tro och övertygelse, snarare än medvetna försök att avgränsa kunskaps- och uppgiftsområden.

Carlhed visar att Bourdieus specifika bidrag till professionsstudierna består av följande. För det första visar hon Bourdieus betoning av socialiseringsmekanismer till fälten. För det andra hur detta löser upp begrepp som profession och klass och ger ett bredare perspektiv på dominansrelationer mellan dessa klasser, vilket skapar sociala och kulturella strukturer och hierarkier samt sammanhållning och drivkrafter i fältet. För det tredje visar hon att det fältteoretiska analysarbetet 
också ger en del metodologiskt intressanta bidrag. För att studera ett fälts autonomi behöver man undersöka strukturlikheter mellan det s.k. rummet av sociala positioner respektive rummet av möjligheter. Rummet av sociala positioner bygger på de sociala bakgrundsfaktorerna, som till exempel utbildningskapital, socialt, ekonomiskt och politiskt kapital. Vem säger vad och från vilken position? Kartläggningen av kapitalformerna och deras volym sker ofta med s.k. prosopografi - ett slags kollektivbiografi. I rummet av möjligheter regerar den specifika ekonomin för symboliskt kapital, som vilar på fältspecifika trosföreställningar. I studier av professionell praktik handlar det om att få fatt i t.ex. kåranda, yrkesetik, mytbildning och ideologiarbete. Slutligen beskrivs den korrespondensanalytiska metoden i studier av professionella fält och praktiker.

Lennart G Svensson söker i sitt bidrag sätta in professionella yrkesutövare och deras arbete i organisatoriska sammanhang genom en uppsättning begrepp som rör kontroll, styrning och ansvar. Exempel på detta hämtas från tre verksamheter: sjukvård, skola och socialtjänst. Särskilt uppmärksammas motsättningar mellan kollegialitet och byråkrati samt yrkesprofessionalism och organisatorisk professionalism, dvs. professionalism i relation till såväl professionella yrkesförbunds kollegiala auktoritet som byråkratiska arbetsorganisationers rationellt-legala auktoritet. Professionella yrken skiljer sig från andra yrken genom att det ofta handlar om komplicerade bedömningar i enskilda fall med hjälp av generella kunskaper, dvs. utövande av diskretion är utbrett. Detta gör arbetet svårt att övervaka och kontrollera.

Svensson urskiljer i första delen fyra olika kontroll- eller styrningsformer kopplade till fyra former av legitimitet: politisk legitimitet där politikerna kan tillsättas och ställas till ansvar i fria demokratiska val; byråkratisk legitimitet där lagar och regler tillämpas generellt av sakliga, opartiska och neutrala tjänstemän som kan ställas till ansvar i en hierarki; marknadsmässig legitimitet där individer valfritt fattar beslut under eget ansvar i en bytesrelation mellan säljare och köpare; professionell legitimitet som baseras på kunskap och kompetens i sin tur baserad på kollegialt kontrollerad vetenskap och beprövad erfarenhet jämte etik. Kollegial organisationsform utmärks av likhet och samarbete mellan kollegor, ibland med olika formell kompetens ofta baserad på legitimation eller auktorisation samt en inre självkontroll kollegor emellan.

I artikelns andra del visar Svensson hur styrning och ansvar praktiseras på ett antal arenor: utbildning, arbetsorganisationer, yrkesorganisationer, i relationer till klienter eller motsvarande mottagare samt $i$ form av kvalitetsstyrning. Resultaten av den undersökningen visar bland annat att avreglering, målstyrning och ramlagar har försvagat förvaltningsstyrning till förmån för vissa marknadsliknande och kundinriktade former för valfrihet samt organisationsstyrning $\mathrm{i}$ arbetsorganisationer och deras ledningar att sätta mål, att bestämma åtgärder och att mäta effektivitet. Nya former av resultatstyrning har införts och delegerats. Kollegial professionell styrning och ansvar för både val av professionella tjänster och utförande (diskretion) har

Lennart G Svensson: Inledning till studier av professioner.. 
därmed tenderat att minska. Rätten att utkräva ansvar har förskjutits från det politiska samhällsuppdraget och från professionell kollegialitet baserad på kunskap och etik till organisationsledningars effektivitet och mottagarnas behovstillfredsställelse. I den utsträckning utvärderingar kontrolleras av externa aktörer har också därigenom skett en förskjutning av kontrollen bort från intern kollegial kontroll och därmed också den etik som professionella är bärare av genom att tillhöra sådana professionella organisationer som Läkarförbundet, lärarförbunden eller Socionomförbundet.

Anders Molander diskuterar i sitt bidrag begreppet skön (eller på engelska discretion). Bedömningar under osäkerhet och ett arbete som är svårt att kontrollera, gör att skön ofta är kännetecknande för professionellt arbete. Att avskaffa skön skulle vara liktydigt med att avskaffa möjligheten att utföra professionellt arbete. (Evidensbasering kan ju sägas vara metoder för att begränsa effekterna av skön.) Professionell autonomi anses tillåata beslutsfattande på grundval av skönsmässiga (eller diskretionära) omdömen. Molander skiljer på skön som en strukturell dimension från en epistemisk, kunskapsmässig dimension. I strukturell mening betecknar skön ett område där man kan välja mellan tillåtna handlingsalternativ på grundval av sitt eget omdöme. En beslutsfattare har skönsbefogenhet när maktutövningen innebär att göra val mellan möjliga alternativ för handling. (Där kan då också utkrävas ansvar.) I epistemisk mening refererar skön istället till en form av resonemang som resulterar i omdömen om vad som bör göras i situationer av obestämdhet, alltså den kognitiva aktivitet som personer med skönsbefogenhet utför, förutsatt att de har för avsikt att fatta skönsmässiga beslut på ett förnuftigt sätt. Och det är ju vad vi förväntar oss av professionella. Molander skisserar en begreppsram för att analysera skön i professionellt arbete i epistemiska termer. Det blir en form av resonemang, som identifierar normativa problem vilka uppstår vid skönsmässiga bedömningar.

I epistemiska termer är skön en form av praktiskt resonemang som syftar till slutsatser om vad som bör göras i specifika fall - och där de s.k. garanterna (slutledningsreglerna) är svaga. Det finns inneboende spänningar mellan detta slags resonemang och kraven på komparativ konsistens. Variation och godtycklighet kan förklaras av det Molander kallar skönsmässighetens bördor (t.ex. komplexitet, viktning och vaghet) och den utbredda tilliten till heuristik, dvs. genvägar eller olika typer av gissningar i slutsatser utifrån vardagserfarenheter. Detta utgör betydande problem i moderna välfärdsstater. Det är också ett problem för tilliten till professioners bedömningar och beslut. Skillnaden, konstaterar Molander, går mellan variation som beror på slarviga skönsmässiga omdömen och variation som beror på väsentliga drag hos skönsmässiga resonemang eller heuristiker. Det går att göra något åt slarv. Den mest drastiska åtgärden är att avskeda dem som är slarviga. Men det är svårare att göra något åt bördor och heuristiker i skön utan att avskaffa skön som sådant. Skön är resonemang med svaga garanter, och det kan man inte göra mycket åt. Det viktigaste är, menar Molander, att bli medveten om skönsmässighetens bördor och heuristikers inflytande, så att man kan förstå varför personer som resonerar nog- 
grant och samvetsgrant, ändå kan nå olika slutsatser om ett fall och begå kognitiva misstag. Att bli medveten är första steget, men det behöver inte vara det sista.

Anna Dunér och Elisabeth Olin rapporterar i sitt bidrag en egen studie av den kommunala funktionshinderverksamheten och äldreomsorgen, två av de största yrkesområdena i landet. Baspersonalens arbete där är att ge stöd och omsorg som innefattar vardagliga sysslor som hushållsgöromål, personlig hygien, gemenskap och aktivering men också stöd av mer psykologisk karaktär. Forskning om professionalisering har sällan rört baspersonal inom dessa verksamheter. Syftet med studien är därför att utifrån arbetsledningen beskriva och analysera aspekter av baspersonalens professionalisering i dessa verksamheter, med avgränsningar och kompetenskrav i jämförelse. Flera utredningar visar att samhället står inför stora framtida utmaningar när det gäller kompetensförsörjning och att en stor andel av de anställda fortfarande saknar formell yrkesutbildning. Socialstyrelsens utredare slår fast att all personal bör ha grundläggande yrkeskompetens för sitt arbete, vilken i huvudsak bör utvecklas inom gymnasieskolans omvårdnadsprogram, gärna kompletterad med en specialiserad kompetens inom socialt arbete, pedagogiskt arbete eller hälso- och sjukvård. Studier har emellertid visat att omvårdnadsutbildningar har bristande legitimitet hos chefer och personal inom funktionshinderverksamhet och äldreomsorg. Andra forskare har tidigare varnat för konsekvenserna av att öka baspersonalens professionella status genom högre utbildningsnivå. Det "goda omsorgsarbetet" ansågs istället bäras upp av praxiskunskap och kunskap om enskilda brukare. Olika uppfattningar kan alltså urskiljas kring vad som är den viktigaste kompetensen för ett kvalitativt gott omsorgsarbete.

Dunér och Olin kan visa tecken på en viss professionaliseringsprocess. Men det är en splittrad bild med ambivalens. Ska man ställa krav på en teoretisk kunskap eller kompetens som främst handlar om personlig lämplighet och att låta övrig kunskap utvecklas under yrkesutövningen? Och högre kompetens motarbetas, enligt informanter, från fackligt håll. Andra studier visar också att brukarorganisationernas inställning rörande kompetens varierar mellan de olika verksamheterna. En uppfattning som Dunér och Olin rapporterar från fokusgrupperna är att teoretisk kunskap inte behöver stå i motsats till praxiskunskap, utan kan istället ses som en förutsättning för situationsanpassning och ökad etisk medvetenhet. Men det finns också de informanter som ser ett motsatsförhållande mellan olika typer av kunskap och framhåller att alltför teoretiskt utbildad baspersonal riskerar att förlora den flexibilitet och situationsanpassning som krävs för att utföra arbetet. Om baspersonalen gör "gemensam sak" med verksamheternas ledning, är ett angeläget ämne för vidare studier. I denna studie framkommer dock att personer i ledande och strategiska positioner tar på sig rollen som ställföreträdande "professionaliseringsagenter" för baspersonalen. Den är ett exempel på en jämförande fallstudie som är en föredömlig ansats i professionsstudier. 


\section{Referenser}

Abbott, Andrew (1988) The System of Professions: An essay on the division of expert labor. London: The University of Chicago Press.

Ackroyd, Stephen (1996) Organisation contra organisation: Professions and organisational change in the United Kingdom. Organization Studies, 17(4): ss. 599-621.

Alvesson, Mats (2001) Organisationskultur och ledning. Malmö: Liber.

Alvesson, Mats (2002) Kommunikation, makt och organisation: Kritiska tolkningar av ett informationsmöte i ett företag. Stockholm: Norstedts juridik.

Björkdahl Ordell, Susanne (1990) Socialarbetare: Bakgrund, utbildning och yrkesliv. Avh. Göteborg studies in educational sciences 74 .

Brante, Thomas (1987) Sociologiska föreställningar om professioner. I Bergryd, Ulla (red.) Den sociologiska fantasin - teorier om samhället. Sthlm: Rabén \& Sjögren, ss. 124-154.

Brante, Thomas (2011) Professions and sciencebased occupations. Professions and Professionalism, volym 1, nr 1. http://journals.hioa.no/ index.php/pp/article/view/147

Brint, Steve (1994) In an Age of Experts: The Changing Role of Professionals in Politics and Public Life. New Jersey: Princeton University Press.

Einarsdottir, Torgerdur (1997) Läkaryrket i förändring: En studie av den medicinska professionens heterogenisering och könsdifferentiering. Avh. Sociologiska inst. Göteborgs universitet, monografi nr 63.

Evetts, Julia (2010) Reconnecting professional occupations with professional organizations: risk and opportunities. I Svensson, Lennart G \& Evetts, Julia (red.) Sociology of Professions. ss. 123-144.

Faulconbridge, James \& Muzio Daniel (2008) Reinserting the professional in the study of PSFs. Global Networks 7(3): ss. 249-270.

Fournier, Valerie (2000) Boundary work and the (un)making of the professions. I Nigel, Malin (red.) Professionalism, Boundaries and the Workplace. London: Routledge.

Fransson, Ola \& Jonnergård, Karin (red.) (2011)
Tillit och förtroende: Ständiga utmaningar för professioner. Lund: Gleerups.

Freidson, Eliot (1970) The professions of medicine. New York: Dodd, Mead \& Co.

Freidson, Eliot (1986) Professional Powers: A study of the institutionalization of formal knowledge. Chicago \& London: The University of Chicago Press.

Freidson, Elliot (2001) Professionalism: The third logic. Oxford: Polity Press.

Hanlon, Gerard (1998) Professionalism as Enterprise: Service Class Politics and the Redefinition of Professionalism. Sociology, volym $32 \mathrm{nr}$ 1 febr, ss. 43-63.

Holmberg, Sören; Weibull, Lennart \& Oscarsson, Henrik (red.) (2011) Svenska trender 19862010. SOM-institutet, Göteborgs universitet.

Kullberg, Karin (2011) Socionomyrket: Om vägar genom yrkeslivet $i$ en av välfärdsstatens nya professioner. Avh. Inst. för socialt arbete, Göteborgs universitet, skriftserie nr 3 .

Liljegren, Andreas \& Parding, Karolina (2010) Ändrad styrning av välfärdsprofessioner exemplet evidensbasering i socialt arbete, Socialvetenskaplig tidskrift, nr 3-4, ss. 270-288.

Molander, Anders \& Terum, Lars Inge (2008) Profesjonsstudier - en introduksjon. I Molander, Anders \& Terum, Lars Inge (red.) Profesjonsstudier. Oslo: Universitetsforlaget. ss. 13-28.

Molander, Anders \& Terum, Lars Inge (red.) (2008) Profesjonsstudier. Oslo: Universitetsforlaget.

Muzio, Daniel \& Kirkpatrick, Ian (2011) Introduction: Professions and organizations - a conceptual framework. Current Sociology, volym 59:4, ss. 389-405.

Noordegraaf, Mirko (2011) Remaking professionals? How associations and professional education connect professionalism and organizations. Current Sociology, volym 59 nr 4 ss. 465-488.

Olofsson, Gunnar \& Petersson, Otto (red.) (2011) Med sikte på profession: Akademiska yrkesutbildningar vid ett nytt universitet. Lund: Arkiv förlag.

Persson, Sofia (2008) Läraryrkets uppkomst och förändring: En sociologisk studie av lärares 
villkor, organisering och yrkesprojekt inom den grundläggande utbildningen i Sverige ca 18002000. Avh. Göteborg studies in sociology nr 33. Sarfatti-Larson, Magali (1977/1979) The Rise of Professionalism: A sociological analysis. Berkeley: University of California Press.

SCB, Kön och utbildning. Temarapport 2010:1.

Sciulli, David (2010) Structural and institutional invariance in professions and professionalism. I Svensson, Lennart G \& Evetts, Julia (red.) Sociology of Professions: Continental and AngloSaxon traditions. Göteborg: Daidalos.

Stenlås, Niklas (2011) Läraryrket mellan autonomi och statliga reformideologier. Arbetsmarknad \& Arbetsliv, årgång 17:4, ss. 11-28.

Svensson, Lennart G \& Ulfsdotter Eriksson, Ylva (2009) Yrkesstatus: En sociologisk studie av hur yrken uppfattas och värderas. Sociologiska inst. Göteborgs universitet. http:// gupea.ub.gu.se/bitstream/2077/19737/1/ gupea_2077_19737_1.pdf

Svensson, Lennart G (2002) Professionella villkor och värderingar: En sociologisk studie av akademiker i 1990-talets Sverige. Rapport 126, Sociologiska inst. Göteborgs universitet. http:// gupea.ub.gu.se/bitstream/2077/23154/1/ gupea_2077_23154_1.pdf

Svensson, Lennart G (2011) Ny professionalism, förtroende, tillit och kompetens.

I Fransson \& Jonnergård (red.) Tillit och förtroende. ss. 23-40.

Svensson, Lennart G \& Evetts, Julia (red.) (2010) Sociology of Professions: Continental and AngloSaxon traditions. Göteborg: Daidalos.

Wingfors, Stina (2004) Socionomyrkets professionalisering. Avh. Göteborg studies in sociology nr 20. 